\title{
The relevance of social history to the interpretation of the Gospel according to John
}

U Busse

\section{ABSTRACT}

The relevance of social history to the interpretation of the Gospel according to John

The relevance of a socio-historical reading of John's Gospel is illustrated through the analysis of John 2:1-11, 8:33-36 and 21:7. In each case a social senario of a particular situation is presented by utilizing different ancient sources. The results are then applied to the mentioned passages in John's Gospel in order to illustrate the relevance of a socio-historical reading of John.

Although exegesis has once more renewed its interest in ancient social history ${ }^{1}$, one gets the impression that the Gospel according to John ${ }^{2}$ has remained untouched by this most welcome development. It is certainly true that the Gospel and Acts of Luke and Paul's correspondence ${ }^{3}$ are the most rewarding objects of research. Nevertheless, there is also a large number of texts in the other scriptures that would become considerably more accessible if a socio-historical comment were to be added. The metaphoric "text-world" of John's Gospel, for instance, if seen against the background of social history, reveals the complex associations that the lecture of this text would have evoked in the original reader. Thus the "world of the reader" is illuminated brighter than ever. An "I-am-word" in which Jesus claims to be the Bread of Life (John 6:35), for example, is based on a real life experience that today's reader in Old Europe cannot easily follow, because he can readily obtain his bread from the bakery every morning. However, as soon as Peter Garnsey's ${ }^{4}$ essay is consulted for the understanding of this text, the "textworld" becomes more vivid and reaches out to the first reader, asking him to associate the word with his own dailybread-experience and to consider the soteriological relevance of the statement. In this way, id est through the reader's adding his own experience to the assertion, the theological value of the statement Jesus makes, according to John, namely to be able to satisfy man's basic needs, is also communicated on an emotional level. 
In this paper I would like to discuss the great importance of this approach with regard to the exegesis of the Gospel according to John. To exemplify my point of view I have chosen the less imposing but, in my mind, nevertheless fundamental topic of the lower service 5 . It belongs to the semantic field of "slavery", namely "service", and mainly appears in the story of the marriage at Cana, in chapter 8 , in the extensive farewellscene and in the final chapter, chapter 21 . I shall accordingly deal with those passages consecutively. However, I shall only touch upon the farewell speeches in passing.

\section{SOCIAL HIERARCHY IN JOHN 2:1-11}

Referring back to John 1:50-51, the comment in John 2:11 reminds the reader that the previous tale should have been read from the same perspective as that of the disciples, id est from the perspective of a believer. Only when looking at the story from this point of view, its symbolism concerning the "glory" or, more biblically speaking, its "importance" 6 can be understood adequately. Thus, all elements of the story have to be considered in order to grasp the intended transparence of the symbolism. The wedding is not documented fully, but only in a sectoral, literary manner: the guest-list is obviously incomplete 7 ; the bride and parents are just of marginal importance; even the sumptuous banquet, which customarily is part of such a feast, remains unmentioned; and finally, the narration sets in at such a late point in the plot that the wedding, which lasts for several days, is reduced to a drinking party. It becomes clear that the reader is intended to perceive only this small section of the event. The narration sets in when the host discovers himself to be in an embarrassing predicament, which, according to Plutarch ${ }^{8}$, is equivalent to losing face, jeopardizing his dignity. Only one thing can be worse for the host's social reputation than this embarrassment: "A host who runs out of bread and wine to my mind is less ridiculous than someone who has not got enough room or seats for the invited guests". Plutarch's grandfather Lamprias continues to explain that a host who is short of bread and wine can at least claim that there must be thieves among his servants. It is precisely this miscalculation in the planning of the feast that Jesus' mother tries to amend by appealing to her Son for help. In the following dialogue between mother and Son the determining precondition for Jesus to act is named: He is temporally limited to "the hour". Only later in the gospel will the reader discover the full meaning of this specific "hour": it is the hour that the heavenly Father and the Son have agreed upon for the 
passion, which is part of Christ's glorification ${ }^{9}$. But all this remains still unmentioned, so that the first reader in particular is instead encouraged to look for clarification in the ongoing narration.

The story continues with Jesus' mother instructing the servants to follow all her son's orders. They fill the pitchers with water, and a sample is taken to the head-waiter or $\dot{\alpha} \rho \chi \imath \tau \rho i k \lambda \iota \nu o \varsigma$. When he tries the drink, he notices the excellent quality of the wine and asks to speak to the bridegroom. For good reason, as it seems, he reprimands the host, and, in doing so, makes it publicly known that the shortage has surprisingly been overcome. Before this, however, in the form of a parenthesis, the question of the mysterious origin of the wine is considered solved: the servants who pulled up the water for the sample will naturally know about it. Thus it can already be stated at this point, that the head-waiter and the bridegroom are contrasted with the servants.

In order to avoid the question, why this factually unimportant aspect is highlighted even through the choice of words, interpretation has so far opted for a literary critical explanation ${ }^{10}$. However, looking at the text from the point of view of a social historian, a much more plausible solution presents itself. Assuming that even the original reader would have

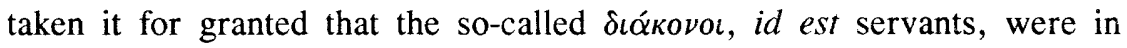
actual fact slaves ${ }^{11}$, the social position of the head-waiter has to be clarified because he was in a position to rebuke the bridegroom. So far this has never been done yet, because the term appears only once more ${ }^{12}$ in Greek literature, namely in Helidor, Aethiopica 7,27.

Wettstein ${ }^{13}$ would have yielded further information: to begin with, he names the Latin equivalent, namely convivator, and also refers to related terms that we know from literature, inscriptions and papyri which could have helped understanding it. The word John uses, which is so rarely found in literature, also has an analogy, $\tau \rho \iota k \lambda \iota \nu \iota \alpha ́ \rho \chi \eta \varsigma$, for which there exists a corresponding Latin loanword. Moreover, the title $\sigma u \mu \pi$ ooi $\alpha \rho \chi \sigma \varsigma$ or $\sigma v \mu \pi \sigma \sigma i \alpha \rho \chi o \varsigma$ (toast-master) ought to be compared to that of headwaiter. It is a fact known to historical linguists, that the prefix " $\dot{\alpha} \rho \chi(\iota)-$ ", which "could be attached to any word at will, in Koine" 14 was growing in popularity. When the Graeco-Roman world of employment became increasingly differentiated due to structural changes in the economy ${ }^{15}$, this prefix appears to have been used to denote a leading position in public or private life. When, in this case, the servants are ordered to take a sample of the wine to the head-waiter, it appears that he is the person in charge of the organisation of the event, which was momentarily threatened by the lack of wine. Proof for the fact that a person whose taste it was to relieve the host 
of the organisational burden of a feast, was not only employed at the Caesar's court, but also for private festivities, can be found in Horace II.serm.8.23-26. In this satire, a Nomentanus is mentioned. At a banquet for the visiting Maecenas, Nomentanus rests next to the host and maintains close social contact with the guest of honour. The latter was mainly in order to anticipate his, and of course also every other guest's wishes and desires, so that he could immediately instruct the servants. Thus he is the host's right-hand-man ${ }^{16}$ who is responsible for the smooth proceedings of social events such as banquets or symposia ${ }^{17}$. That can be proven in a Jewish surrounding too ${ }^{18}$, just as the aforementioned passage in Heliodor, in which the head-waiter Achaimenes complains about Theagenes, supports this view:

\begin{abstract}
"Achaimenes then tried to demonstrate and explain to him something of the art of cup-bearing, but Theagenes ran to one of the tripods on which the cups stood, picked up one of the precious vessels, and exclaimed: "I have no need of teachers! I shall use my instinct in serving my mistress..." Achaimenes, for his part, had suffered a wound of a different kind... "That young foreign whippersnapper, "he replied," is held in greater esteem than we are. He has only been here a couple of days, and he is allowed to pour wine at table. Then he bids us, the head-waiters and chief butlers, good day, hands milady a bowl, and stands next to the royal person, without so such as a byyour-leave to us and our superior rank - so called! That this fellow should be promoted above our heads and made intimate to our lady's inmost secrets through our own mistaken silence and connivance is the least of our misfortune, but though it is. But it might at least have been possible for this to be done without humiliating and insulting those of us who have aided and served her in all her honest dealings"19.
\end{abstract}

We now know what the function of a head-waiter was. However, that still does not clarify his social position, for, theoretically, he could be a mere slave who was appointed to this position because of special merits or circumstances. Inscriptions help us approach a more precise understanding of the social rank of the head-waiter. The dedications to Titus Claudius Augusti Libertus Bucolas CIL XI 3612, which have been known for a long time, and other such inscriptions (CL III 536, VT 1884, 9003, 9083) reveal that released slaves often took up such positions. Frequently, as in the case of Bucolas, they had formerly served as tasters. Bucolas then 
became "procurator", responsible for the organization of the Caesar's gladiator-games and later continued his social ascent up to the highly influential post of "procurator" at the Caesar's court. This cursus shows the same tendency. The office of head-waiter is confidential and obviously serves as a stepping-stone from slavery towards liberation. Moreover, it is a proof of a certain tendency towards upward mobility in Roman society. It belongs to the scope of operum liberti which obliged the freedman to his former master.

Knowing this, we can now understand why the head-waiter take the liberty to reprimand the bridegroom. As a confidential person he is in a position to remind his master of the proper customs and proceedings for this event. Thus the impression is confirmed that John's Gospel takes us into a "fairly high and sophisticated stratum of society" 20 . Furthermore, our impression is confirmed that the author is contrasting the head-waiter's ignorance concerning the wine's origin with the slaves' knowledge. In his aim to help the wedding, Jesus is co-operating with the latter group. They are participating directly in Jesus' actual work of redemption, which according to Graeco-Roman legislation takes place at the level of res mobilis ${ }^{21}$. The social climbers have to discover the actual facts themselves. Such knowledge, the author implies, is not found with free citizens and paterfamilias, but only with familiares ${ }^{22}$. The sublime social criticism contained here reveals the presence of an "option for the poor and underprivileged" in the Gospel according to John. Similarly, by washing his disciples' feet in John 13, Jesus sets an example against the disciples, and in particular Peter's prevailing upwardly-mobile values. He caries out the act of hospitality which is normally performed by a slave. Another example of serving like a slave can be found in the Jewish novel Joseph and Aseneth 13:15. In a prayer, Aseneth, an Egyptian princess, says to the Lord:

"My Lord, give me to him as servant and slave, so that I can wash his feet, make his bed, serve him and do what a slave should do (see the function of a servant "a cubiculo" in e.g. CIL VI 8498). In this way I will be his slave all the days of my life".

Looking at the story of the wine miracle from a socio-historical point of view thus restores the socio-critical aspects of the narration and reveals the social breakthrough that divine salvation brought about for this cosmos. 
Central to the argument with the Jew from Jerusalem in chapters 7-10 is the question of affiliation which in a way is resolved through employing legal means and circumstantial evidence. In the first of the five debates, Jesus claims that only the legitimate son remains in his father's house, the slave on the other hand, has to leave it (v 35). This statement is crucial to our issue. There is no evidence of such a law in Graeco-Roman slave-law. Since a slave was a res under this legislation, he could not leave his owner's house on his own initiative ${ }^{23}$. He was normally sold like any other possession, but that did not happen very frequently. A further possibility granted by Roman law was for the siave to buy his freedom. After his manumissio he would be obliged to join the staff of his former owner and to perform certain duties. According to the Bible ${ }^{24}$, however, Jewish slavelaw was somewhat different: ever since the introduction of the Jubilee in the second half of the sixth century BC, slaves, who were mostly children sold into slavery because of debts (cf Neh 5:1-13), were released from slavery in this seventh year. If the enslaved Jews in the diaspora were lucky, a synagogue would pay for their release (cf CPJ III $473=$ P.Oxy. 1205). The Mishna Berakot 3.3-4 and 4.1 also exhibit a differrent attitude towards slavery, when they demand that slaves should participate in the synagogue prayer, respectively the Shema Israel. This regulation protects the slaves' basic rights as members of the covenant ${ }^{25}$. In ancient Judaism, slavery was legally speaking a relatio, id est an obligation to work with limited rights on a temporary basis.

Now that we have looked at the various types of slave-laws, we know that the author of John 8 presupposes Jewish conditions and a Jewish background. Thus the text has to be read differently: allegedly part of the inhabitants of Jerusalem had become believers, as verse 30 supports in the rare genetivus absolutus. This gives the author an opportunity to let Jesus scrutinize this change of faith. As already mentioned, this will happen in five debates, all of which follow the same literary model: a statement is followed by a misunderstanding and then finally a clarification. The first trial begins with the statement that, if the newly confirmed people were truly loyal, they would naturally understand the truthfulness of Jesus' words and become free. The addressed misunderstand this. They think that this is a hint that they will be robbed of their tradition and identity as children of Abraham, because Jesus claims that he himself was sent by the heavenly Father. Then Jesus clarifies His point, beginning with an AmenWord. However, this explanation is not very transparent and requires good 
knowledge of the Bible, as Jesus answers their objection very globally by remarking that everybody who is guilty is also enslaved by that guilt. Therefore, such a slave could not stay in his father's house like a son. At this point the author contextually introduces the two sons of Abraham into the argument: on the one hand there is Isaac, the legitimate son, on the other hand there is Ismael, whose mother was the slave Hagar. According to Genesis $16: 12-15 ; 21: 10$ and following, Ismael and his mother had to leave his father's tent. This Biblical tradition plays an important role in the argumentation of the New Testament ( $\mathrm{cf} \mathrm{Gal} \mathrm{4).} \mathrm{When} \mathrm{Jesus} \mathrm{accuses} \mathrm{the}$ inhabitants that they want his death in spite of being undeniably Abraham's children (even if they might be illegitimate ones), this strange line of reasoning also belongs into the context of the story of Ismael and Isaac. In early Jewish tradition, the theme of Ismael playing with the younger, but legitimate son Isaac is often understood as an attempt of the older one to kill his younger brother, for instance in a game of bow and arrows, or to harm him (Fl Jos Ant. I $215=1.12 .3$ ) or lead him into temptation (Targum Pseudo-Jonathan, Targum Jerushabini, Targum Neofiti 1 on Genesis $12: 9)^{26}$. Only if knowing about Jewish tradition, Jesus' apodictical statement that a slave could leave the house of his Lord can be understood correctly.

\section{PETER'S ODD BEHAVIOUR ON THE FISHING BOAT: JOHN 21:7}

In John's fishing story, Peter's reaction to the beloved disciple's remark that the Lord is standing on the shore, is difficult to understand. The observation caused Peter, who was naked, to get dressed in a hurry27, gather up his clothes and then jump into the water, fully dressed - a truly eccentric reaction. He consequently reached the shore too late, because, as a matter of fact, the boat had only been 200 cubits away from the beach. What used to cause bewilderment in this scene, was Peter being described as naked. "He robed himself in order to appear decently in front of the Lord", was one of the explanations traditional exegesis ${ }^{28}$ would give. However, this does not take the fact into consideration that fishing naked or just wearing a chiton was normal fishing practice in those days. This was done for practical reasons, as people did not have oil-cloth yet. So this detail of the story only serves as an illustration of what kind of clothing was worn for fishing. Truly astonishing, on the other hand, is the fact that Peter got fully dressed - as if he had had the bag with his clothes on board with him. The fact that he gathered up his clothes before jumping 
overboard is even more surprising, because in the ancient world people usually swam naked ${ }^{29}$. However, the reader of those days would have immediately understood what this peculiar behaviour indicated, particularly because the focus on the exact number of fishes caught, marks the story as highly symbolical. On the other hand, Peter's behaviour remains mysterious. Gathering up his clothes indicated that Peter intended to work. Already in John 13:4 (cf also Luke 12:35, 17:8; Horace, II. serm 8.10), there was mention of Jesus gathering up his clothes before he served his disciples like a slave. Thus, for the ancient reader, Peter's jumping overboard dressed does not only imply that he wants to get to the shore, but the way that he is dressed primarily signals his readiness to work. As a consequence, it is he who pulls the net containing the 153 fishes to the shore. In this way, he creates the precondition for the Resurrected to order the other disciples to catch more fish for the communal breakfast. In providing the basis for the other disciples to follow Jesus' orders, Peter is setting an example of how the explicit command to love each other, which Jesus expressed in his farewell speech, can be followed in a post-Easterly way (e g John 15:10-16). Peter's serving the group of disciples and their Lord exhibits the Easterly turning point in his life: he is an example of someone who was as ignorant as a slave at first, and then entered the bond of friendship with Jesus because he obeyed his Lord (John 15:15).

After this, it is only logical that Jesus appoints Peter to the office of the shepherd. Both Jesus and the reader know from Peter's previous reaction that he is willing and able to take over the pastoral role as already defined in chapter ten, even if this would mean risking his own life (cf John 15:13 and 21:18-19). Thus, the mystery of Peter's strange behaviour on board the fishing boat can be resolved through taking the context into consideration. In his martyr's death he is exactly where he should be according to John 12:26: he is where his Lord is.

\section{RESULTS}

Although not all aspects of John's word-field around the "lower service" could be discussed at this point, the examples have shown that a supplementary analysis under socio-historical aspects can add considerably to the understanding of the texts. It can reveal details that would be easily overlooked in an exclusively theological exegesis of the Gospel according to John, or in an interpretation which aims mainly at Christological results. Moreover, highly symbolical texts can only receive an adequate hermeneutical interpretation by the modern reader, if he is simultaneously informed 
about the socio-historical "relevance to life" which is contained in the metaphors. Finally, this approach occasionally can make literary critical operations superfluous, because the assumption of older literary sources only shifts the lack of explanation, but it does not resolve it.

\section{NOTES:}

1 Especially G Heinrici, E von Dobschütz, A Deißmann in Germany and the Chicago School in the United States of America had very early at the turn of the century already recognised the importance of social-historical knowledge for the New Testament exegesis. From there the interest in this problem returned to Europe in the last two centuries. Cf inter alia E A Judge, The social pattern of Christian groups in the First Century, London 1960; J G Gager, Kingdom and community. The social world of early Christianity, New Jersey 1975; W A Meeks, The first urban Christians. The social world of the apostle Paul, London 1983; G Theißen, Studien zur Soziologie des Urchristentums, Tübingen 1979; A J Malherbe, Social aspects of early Christianity, London 1977; J E Stambaugh \& D L Balch, The New Testament in its social environment, Philadelphia 1986; L Schottroff \& W Stegemann, Jesus von Nazareth - Hoffnung der Armen, Tübingen 1978.

2 From the social-historically orientated literature that has come to my knowledge it is only G Theißen, op cit, footnote 303 and G Theißen, Lokalkolorit-forschung in den Evangelien, EvTh 45 (1985) 481-499,490 who has aired a view on the themes selected here.

3 Cf the works mentioned by and also P Marshall, Enmity in Corinth: Social conventions in Paul's relations with the Corinthians, WUNT 2/23, 1987; See W Stegemann, Zwischen Synagoge und Obrigkeit, Göttingen 1991, for the historical situation of the Lukan Christians.

P Garnsey, Famine and food supply in the Graeco-Roman world: Responses to risk and crisis, Cambridge 1988; P Garnsey \& C R Whittaker (eds), Trade and famine in classical antiquity, Cambridge 1983.

Cf J P Louw \& E A Nida, Greek-English Lexicon of the New Testament based on semantic domain, Cape Town 1989, I, 460-464.

See C Westermann, Art: "kabod", Theologisches Handwörterbuch zum Alten Testament I München 1971, 794-812; cf M Weinfeld, Art: "kabod", Theologisches Wörterbuch zum Alten Testament IV, Berlin 1984, 23-40.

According to Plutarch, Moralia $679 \mathrm{C}$ and D especially all relatives had for example to be invited to the wedding. 
So amongst others E Haenchen, John. A commentary on the Gospel I, ed by U Busse and translated by R W Funk, Philadelphia 1984, 178 and following.

10 To this temptation I myself have already succumbed: Cf U Busse \& A May, Das Weinwunder von Kana (Joh 2:1-11), BN 12 (1980) 35-61.

11 See Apuleius, Metamorph. II 2.3; II 19; Petronius, Satyrica 27ss; Horace, I Serm 6.105 , where there is referred mainly to a large number of slaves with special tasks.

12 Cf H G Liddell-R Scott, Greek-English Lexicon, Oxford 1982, 253.

13 J Wettstein, Novum Testamentum Graecum I Amsterdam 1752, 847.

14 So G H R Horsley (ed), New documents illustrating early Christianity 2, 1982,18 with further literature references. The quotation itself stems from $\mathbf{H}$ K Moulton, The vocabulary of the Greek Testament, 1930, 80; cf also 81 and following.

15 Cf T Pekáry, Die Wirtschaft der Griechisch-Römischen Antike, Wiesbaden 1979, 93-95; H Kloft, Die Wirtschaft der Griechisch-Römischen Welt. Eine Einführung, Darmstadt 1992, 186 and following; J Bleicken, Verfassungsund Sozialgeschichte des römischen Kaiserreiches, Göttingen 1981, I 332341, II 55-76.

16 A further proof of the social position of a head-waiter can be found in Martial IV 8. There the author requests a certain Euphemus, the head-waiter of Domitian, to hand the Emperor his poems at the meal.

17 Proofs for the frictionless course of a symposion are to be found inter alia in Plutarch, Moralia 298c; 619E-622B; 679B; Horace, II.serm 8.

18 SiphreDt 11,10 (77a); cf P Billerbeck, Kommentar zum NT aus Talmud und Midraschim, München 1926, I, 500 and following.

19 Translated by B P Reardon in his Collected ancient Greek novels, Berkeley 1989, 514 and following.

20 G Theißen, op cit, footnote 490.

21 A slave was not regarded as a human being, but a movable object or commodity.

22 Cf Genesis 18:4; 19:2; 24:32; 43:24; Judges 19:21; 1 Samuel 25:41; Luke 7:44; 1 Timothy 5:10; Philo, Quaestiones Genesis IV 5.60; Quaestiones in Exodum 1:2; de vita Mosis II 138; De secialibus legibus I 206f; Testament of Levi 9:11; Tobit 7:9b; Plutarch, Moralia 958B. 
23 Cf Petronius, Satyrica 28.7.

24 Cf Josephus Antiquitates Judaicae 3:12,3; 16:1,1.

25 Cf E Schürer, The history of the Jewish people in the age of Jesus Christ, II, (eds) by G Vermes. F Millar, M Black, Edinburgh 1979, 456,482,568.

26 Cf J H Neyrey, Jesus the judge: Forensic process in John 8:21-59, Bib 68 (1987) 509-542.

27 Further expositions are to be found in U Busse, Die "Hellenen" Joh 12:20ff. und der sogenannte "Anhang" Joh 21, in: Festschrift Frans Neyrynck III, Leuven 1992, 2083-2100,2097-2099.

28 Cf A Maier, Commentar über das Evangelium des Johannes II, Karlsruhe/Freiburg 1843, 411.

29 One proof inter alia should suffice: Heliodor, Aethiopica 2.13,2. 